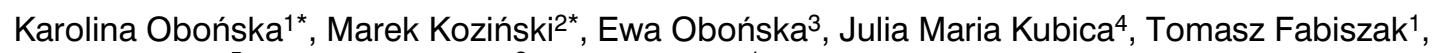
Jarosław Czyż ${ }^{5}$, Grzegorz Grześk ${ }^{3}$, Jacek Kubica ${ }^{1}$

${ }^{1}$ Department of Cardiology and Internal Medicine

2Department of Principles of Clinical Medicine

32Department of Pharmacology and Therapeutics

4Students' Scientific Group, Department of Cardiology and Internal Medicine

5Department of Hematology

Collegium Medicum, Nicolaus Copernicus University, Bydgoszcz, Poland

*Karolina Obońska and Marek Koziński have equally contributed to the present paper and should be considered first authors.

\title{
A systematic review on the role of bivalirudin in patients undergoing percutaneous coronary interventions: primus inter pares or a falling star?
}

\author{
Corresponding author: \\ Karolina Obońska, MD, PhD \\ Department of Cardiology and Internal \\ Medicine, Collegium Medicum, \\ Nicolaus Copernicus University \\ 9 Skłodowskiej-Curie Street, \\ 85-094 Bydgoszcz, Poland \\ Tel.: +48525854023 \\ Fax: +48525854024 \\ E-mail: kalaobonska@op.pl
}

Folia Medica Copernicana 2015; Volume 3, Number 3, 79-88 10.5603/FMC.2015.0001 Copyright (C) 2015 Via Medica ISSN 2300-5432

\begin{abstract}
Intracoronary thrombosis triggered by ruptured or eroded atherosclerotic plaques constitutes the predominant underlying cause of acute coronary syndromes (ACS). Thrombin is considered a central enzyme in hemostasis and thrombosis, and a well-established target for anticoagulant therapies. Bivalirudin was introduced in the clinical practice as a promising, reversible, direct thrombin inhibitor with a predictable anticoagulant effect. Initial randomized clinical trials demonstrated that bivalirudin compared with heparin on top of a glycoprotein $\mathrm{llb} / \mathrm{llla}$ inhibitor was associated with a significant reduction of major bleeding and favorable net clinical outcomes in patients undergoing percutaneous coronary interventions (PCI). The HORIZON-AMI trial even indicated mortality benefit in bivalirudin-treated patients. Thereby, the 2011 and 2012 European Society of Cardiology Guidelines on the management of non-ST-segment elevation ACS and ST-segment elevation myocardial infarction positioned bivalirudin as the anticoagulant of choice in the $\mathrm{PCl}$ setting. Further randomized studies, better reflecting routine clinical practice, revealed significantly increased rates of stent thrombosis and myocardial infarction in the bivalirudin arm. Additionally, these findings were corroborated in the subsequent meta-analyses. Speculations that excessive occurrence of stent thrombosis and myocardial infarction may be caused by too short duration of post PCI bivalirudin infusion did not find confirmation in the latest MATRIX trial. In this systematic review, we aim to assess the efficacy and safety of bivalirudin therapy in patients undergoing $\mathrm{PCl}$ and to formulate recommendations on the bivalirudin use for clinicians. In our opinion, the research evidence and pharmacoeconomic considerations strongly support the use of bivalirudin in $\mathrm{PCl}$ patients at high risk of bleeding complications, while in other situations old and inexpensive UFH or enoxaparin remain the first line antithrombotic drugs. Key words: bivalirudin, thrombin, antithrombotic treatment, acute coronary syndrome, percutaneous coronary intervention
\end{abstract}

Folia Medica Copernicana 2015; 3 (3): 79-88

\section{Introduction}

Coronary artery disease (CAD) remains the leading cause of death worldwide. All over the world over seven millions of people die from CAD annually, which accounts for $13.1 \%$ of all deaths [1]. In Europe, every sixth man and every seventh woman is expected to die from myocardial infarction (MI) [2]. The mainstay of treatment in patients with acute coronary syndromes (ACS) includes intensive antithrombotic and anti-ischemic therapy together with invasive coronary procedures. Primary percutaneous coronary 
intervention $(\mathrm{PCl})$, when compared with thrombolytic therapy, was demonstrated to reduce all-cause mortality as well as re-MI and stroke rates in patients with ST-segment elevation myocardial infarction (STEMI) and therefore, is considered the preferred reperfusion strategy in this setting (class of indication I, level of evidence A) [2]. Additionally, currently the majority of subjects with non-ST-segment elevation ACS also undergo $\mathrm{PCl}$ procedures. In this setting, interventional treatment, when compared with conservative strategy, prevents recurrent episodes of coronary ischemia and in intermediate- to high-risk patients is associated with improved survival and lower risk of $\mathrm{MI}$. $\mathrm{PCl}$ procedures effectively restore patency of culprit coronary arteries and improve myocardial perfusion [3]. Importantly, $\mathrm{PCl}$ interventions are performed in a highly thrombogenic environment. Intracoronary thrombosis triggered by ruptured or eroded atherosclerotic plaques constitutes the predominant underlying cause of ACS events. Exposure of subendothelial proteins to the flowing blood at sites of plaque disruption leads to platelets activation and aggregation as well as to the release of vasoactive and procoagulant mediators. In details, tissue factor (TF) originating from the unstable coronary plaques induces thrombin generation, which may result in the formation of a platelet- and fibrin-rich intracoronary thrombus. Thrombin is considered a central enzyme in hemostasis and thrombosis, and a well-established target for anticoagulant therapies (Fig. 1) [4]. Anticoagulant regimens utilized during $\mathrm{PCl}$ procedures include: unfractionated heparin (UFH), low molecular weight heparins, particularly enoxaparin and bivalirudin [2, 5-9]. Recently, numerous randomized trials on the role of bivalirudin in patients undergoing $\mathrm{PCl}$ have been published. Their inconsistent results, arising from the important differences in study designs and changes in interventional practice, have fueled an ongoing debate on bivalirudin in the cardiological community. Therefore, we aim to conduct a systematic review in order to assess the efficacy and safety of bivalirudin therapy in patients undergoing $\mathrm{PCl}$ and to formulate recommendations on the bivalirudin use for clinicians.

\section{Search strategy}

A systematic investigation of all published and unpublished literature, including oral presentations, was conducted to minimize the risk of bias. Briefly, we followed the PRISMA statement for reporting systematic reviews in health care interventions [10]. A database search including PubMed and Google Scholar databases, without time limitations, was conducted on 3rd September 2015 by two independent investigators (K.O. and M.K.). Proceedings from the Scientific Sessions of the American College of Cardiology (http://www.acc.org), American Heart Association (http://www.heart.org), European Society of Cardiology (http://www.escardio.org) were also considered. The following key words were applied: "bivalirudin", "hirulog", "bivalirudin" and "percutaneous coronary intervention", and "hirulog" and "percutaneous coronary intervention". References of the retrieved studies were searched manually for additional studies and reviews. No language restrictions were applied. Data were abstracted on prespecified forms. All divergences were resolved by discussion with a third investigator (JK). Reviews were also considered a source of citations of the relevant studies and interpretation of their results.

After a systematic search 24,343 citations were identified: 2,661 in PubMed, 17,840 in Google Scholar, and 3,842 in other databases. Duplicate / multiple citations and reviews not containing any relevant information were excluded. Eventually, 44 original reports and

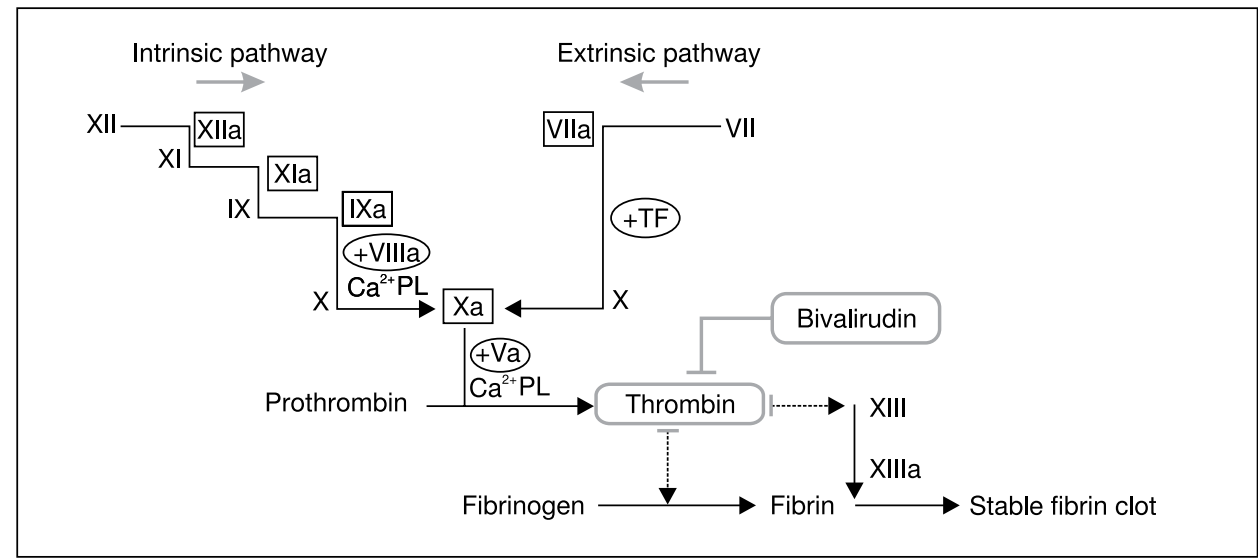

Figure 1. Target of bivalirudin in the coagulation cascade; V, VII, VIII, IX, X, XI, XII, XIII - coagulation factors; a - active form; $\mathrm{Ca}^{2+}$ — calcium ions; $\mathrm{PL}$ — platelet membrane phospholipids; TF — tissue factor 


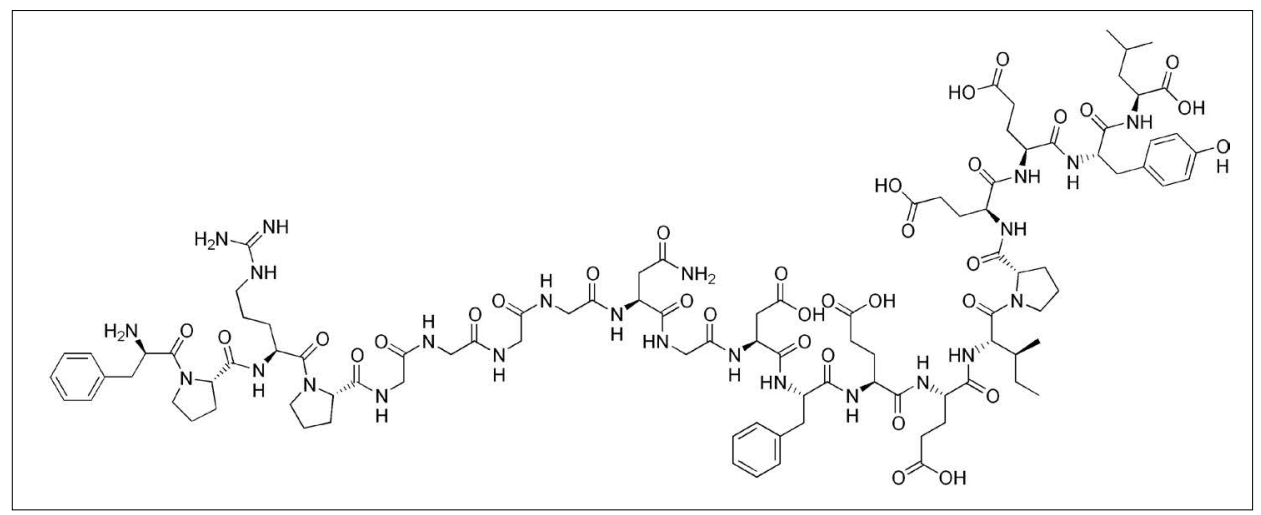

Figure 2. Chemical structure of bivalirudin $\left(\mathrm{C}_{98} \mathrm{H}_{138} \mathrm{~N}_{24} \mathrm{O}_{33}\right)$

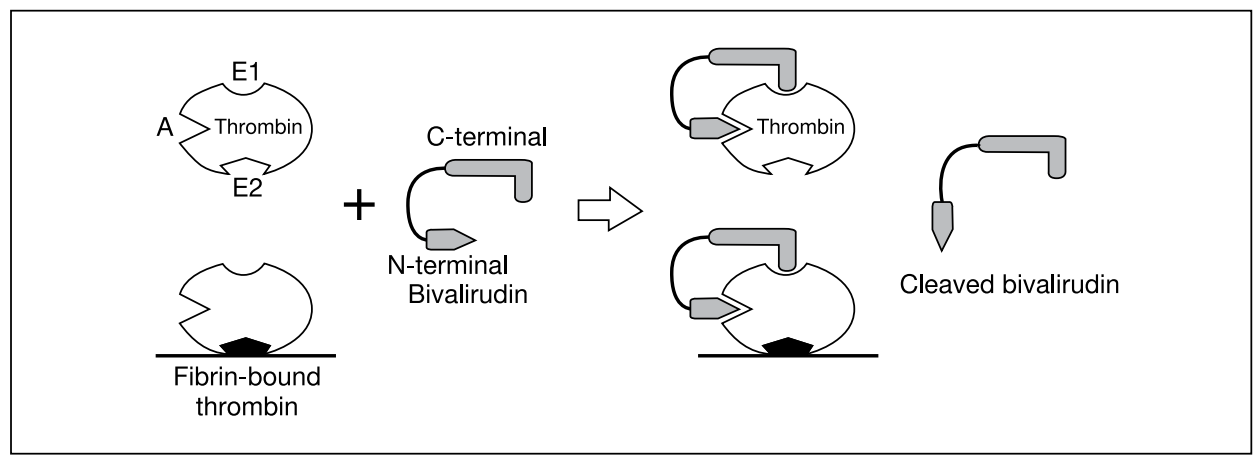

Figure 3. Interactions between bivalirudin and thrombin. Bivalirudin binds to both active site and exosite 1. Bivalirudin inhibits both fibrin-bound and soluble thrombin. Cleaved bivalirudin can be displaced by competitive substrates; A - active site (catalytic site responsible for enzymatic actions of thrombin); E1 - exosite 1 (substrate recognition and fibrinogen-binding site); E2 - exosite 2 (heparin-binding site)

reviews directly related to the rationale for bivalirudin therapy in patients undergoing $\mathrm{PCl}$, pharmacological properties of bivalirudin, and clinical studies on bivalirudin were considered eligible for inclusion in the systematic review.

\section{Pharmacological properties of bivalirudin}

Bivalirudin, a synthetic analog of the carboxy terminus of hirudin, is a reversible, direct thrombin inhibitor (Fig. 2). It exerts a predictable anticoagulant effect, since it does not bind to plasma proteins. Notably, bivalirudin does not require antithrombin for its anticoagulant action and inhibits both fibrin-bound and soluble thrombin (Fig. 3). Additionally, bivalirudin binds to both active site and exosite 1 of thrombin, thereby competing with exosite 1 for fibrin binding and enhancing displacement of thrombin from fibrin. Following its binding to bivalirudin, thrombin cleaves the Pro-Arg bond within the amino terminal of bivalirudin allowing the recovery of thrombin activity. Bivalirudin has a plasma half-life of 25 minutes after its intravenous administration and only $20 \%$ of the given dose is cleared through kidneys $[3,11-13]$. According to the experiments performed by Butenas et al. [14], increasing concentrations of bivalirudin prolong the initiation phase of thrombin generation in a concentration-dependent manner. Interestingly, the investigators demonstrated an increased thrombin generation at subpharmacologic concentrations of bivalirudin (0.5-2.0 $\mu \mathrm{mol} / \mathrm{L})$, however, at a pharmacologic concentration $(5.0 \mu \mathrm{mol} / \mathrm{L})$ bivalirudin effectively suppressed thrombin generation and inhibited platelet activation by around $80 \%$. These observations led to the conclusion that bivalirudin acts not as a modulator but as an 'on-off' switch of blood coagulation [14]. Tanaka et al. demonstrated substantial differences between heparin and bivalirudin in terms of the kinetics of thrombus formation [15]. In the blood samples collected from 12 healthy volunteers, the authors found that increasing concentrations of bivalirudin and heparin progressively delayed the onset of thrombin formation, but only heparin dose-dependently decreased the amount of gener- 
ated thrombin. Importantly, Anand et al. demonstrated an independent from clopidogrel therapy antiplatelet effect of bivalirudin v. UFH during PCI [16]. Moreover, this study showed that bivalirudin alone or coupled with clopidogrel may confer an anti-inflammatory effect by reducing $\mathrm{SCD} 40 \mathrm{~L}$ during $\mathrm{PCl}[16]$. Anti-inflammatory properties of bivalirudin were confirmed in another study including 46 patients undergoing elective $\mathrm{PCI}$ [17]. Platelet surface expression of PAC-1, P-selectin and GP Ib alpha were significantly reduced after $\mathrm{PCI}$ in bivalirudin-treated patients as compared with those receiving UFH. Similarly, CD11b expression on CD14+ monocytes was diminished after bivalirudin administration. Additionally, the opposite effects of heparin and bivalirudin on platelet adhesion were shown in vitro by Eslam et al. [18]. In this study, platelet adhesion increased by $10 \%$ with UFH when compared with the baseline values, while a corresponding decrease by $20 \%$ was observed with bivalirudin ( $p=0.0047)$. Furthermore, in a study by Pepke et al. [19], bivalirudin, but not UFH, reduced post- $\mathrm{PCl}$ expression of $\mathrm{P}$-selectin in unstimulated and adenosine diphosphate (ADP)-induced platelets. Moreover, bivalirudin inhibited the thrombin, but not VIla- or VIla/X-induced TF expression and pro-coagulant TF activity of smooth muscle cells. The observations derived from the above discussed studies suggest that bivalirudin reduces platelet and monocyte activation in patients undergoing PCI [15-19] and therefore bivalirudin seems to be a potentially better anticoagulant than $\mathrm{UFH}$ in this setting.

\section{Results of initial randomized clinical trials: a rising star...}

After initial randomized clinical trials were published, this hope became more realistic. In details, the ACUITY (Acute Catheterization and Urgent Intervention Triage Strategy) investigators randomly assigned 13,819 moderate or high risk ACS patients undergoing invasive management to one of three antithrombotic regimens: UFH or enoxaparin plus a glycoprotein Ilb/Illa inhibitor, bivalirudin plus a glycoprotein Ilb/llla inhibitor, or bivalirudin with bailout use of a glycoprotein Ilb/Illa inhibitor [20]. The use of bivalirudin plus a glycoprotein Ilb/Illa inhibitor, as compared with UFH or enoxaparin plus a glycoprotein Ilb/Illa inhibitor, was associated with similar 30-day rates of the composite ischemia end point (death, MI, or unplanned coronary revascularization for ischemia: $7.7 \%$ v. $7.3 \%$; relative risk [RR] 1.07; 95\% confidence interval [CI] 0.92-1.23; $p=0.39$ ), major bleeding (5.3\% v. 5.7\%; RR 0.93; 95\% $\mathrm{Cl} 0.78-1.10 ; \mathrm{p}=0.38)$, and the net clinical outcome end point (composite of the ischemia end point and major bleeding: $11.8 \%$ v. $11.7 \%$; RR $1.01 ; 95 \% \mathrm{Cl}$
0.90-1.12; $p=0.93)$. Similarly, when bivalirudin was used alone, as compared with UFH or enoxaparin plus a glycoprotein Ilb/Illa inhibitor, there was no difference in the rate of composite ischemia end point $(7.8 \% \mathrm{v}$. 7.3\%; RR 1.08; 95\% Cl 0.93-1.24; $p=0.32)$, but the rates of major bleeding (3.0\% v. 5.7\%; RR 0.53; $95 \%$ Cl 0.43-0.65; $p<0.001)$ and net clinical outcome end point (10.1\% v. 11.7\%; RR 0.86; 95\% Cl 0.77-0.97; $\mathrm{p}=0.02$ ) were significantly reduced. Additionally, at 1 year, no statistically significant differences in the rates of composite ischemia end point or mortality with the 3 compared therapies were found [21].

The most favorable results for bivalirudin among all so far conducted randomized clinical studies were achieved in the HORIZONS-AMI (Harmonizing Outcomes with Revascularization and Stents in Acute Myocardial Infarction) trial [22]. This study included 3,602 STEMI patients undergoing primary $\mathrm{PCl}$. The investigators demonstrated that anticoagulation with bivalirudin alone, as compared with UFH plus a glycoprotein Ilb/Illa inhibitor, resulted in a reduced 30-day rate of net adverse clinical events, defined as the combination of major bleeding or major adverse cardiovascular events, including death, reinfarction, target-vessel revascularization for ischemia and stroke (9.2\% v. 12.1\%; RR 0.76; 95\% Cl 0.63-0.92; $p=0.005$ ), owing to a lower rate of major bleeding (4.9\% v. $8.3 \%$; RR 0.60; 95\% Cl 0.46-0.77; p < 0.001). Importantly, treatment with bivalirudin alone, as compared with UFH plus a glycoprotein Ilb/Illa inhibitor, resulted in significantly lower 30-day rates of death from cardiac causes (1.8\% v. 2.9\%; RR 0.62; 95\% Cl 0.40-0.95; p =0.03) and death from all causes (2.1\% v. $3.1 \%$; RR 0.66 ; $95 \%$ $\mathrm{Cl} 0.44-1.00 ; \mathrm{p}=0.047)$. Unfortunately, there was an increased risk of acute stent thrombosis (within $24 \mathrm{~h}$ ) in the bivalirudin group ( $1.3 \%$ v. $0.3 \%$; $p<0.001)$, but no significant increase was present by 30 days $(2.5 \%$ v. $1.9 \% ; p=0.30)$. At 3 -year follow-up, the superiority of bivalirudin monotherapy over the combination of UFH and a glycoprotein Ilb/IIla inhibitor became even more evident. Compared with 1,802 patients allocated to receive UFH plus a glycoprotein Ilb/Illa inhibitor, 1,800 patients allocated to bivalirudin monotherapy had lower rates of all-cause mortality (5.9\% v. $7.7 \%$; hazard ratio [HR] 0.75; 95\% $\mathrm{Cl} 0.58-0.97 ; \mathrm{p}=0.03)$, cardiac mortality (2.9\% v. 5.1\%; HR 0.56; 95\% Cl 0.40-0.80; $\mathrm{p}=0.001)$, re-MI $(6.2 \%$ v. $8.2 \%$; HR $0 ; 76 ; 95 \% \mathrm{Cl}$ $0.59-0.99 ; p=0.04)$, and major bleeding not related to bypass graft surgery $(6.9 \%$ v. $10.5 \%$; HR $0.64 ; 95 \% \mathrm{Cl}$ $0.51-0.80 ; p=0.0001$ ), with no significant differences in ischemia-driven target vessel revascularization, stent thrombosis, or composite adverse events [23].

Another large study, the EUROMAX (European Ambulance Acute Coronary Syndrome Angiography) trial, tested in 2,218 STEMI patients whether prehospital 
administration of bivalirudin continued for 4 hours after primary $\mathrm{PCl}$ improves clinical outcomes compared with the guideline-recommended UFH or enoxaparin [24]. The investigators revealed that bivalirudin, as compared with the control intervention, reduced the risk of the primary outcome, which was a composite of death or major bleeding not associated with coronary artery bypass grafting (CABG) at 30 days, $(5.1 \% \mathrm{v}$. 8.5\%; RR 0.60; 95\% Cl 0.43-0.82; $\mathrm{p}=0.001$ ) and the principal secondary outcome, defined as a composite of death, re-MI, or non-CABG major bleeding (6.6\% v. 9.2\%; RR 0.72; 95\% Cl 0.54-0.96; $p=0.02$ ). Bivalirudin also reduced the risk of major bleeding (2.6\% v. $6.0 \%$; RR $0.43 ; 95 \%$ Cl $0.28-0.66 ; p<0.001$ ). Similarly to the previously discussed study, the risk of acute stent thrombosis was higher with bivalirudin $(1.1 \%$ v. $0.2 \%$; RR 6.11; 95\% Cl 1.37-27.24; $p=0.007)$. There was no significant difference in rates of death $(2.9 \%$ v. $3.1 \%)$ or re-MI (1.7\% v. 0.9\%) [25].

Based on the results of the above discussed randomized clinical trials, the 2011 and 2012 European Society of Cardiology Guidelines on the management of non-ST-segment elevation ACS and STEMI positioned bivalirudin as the anticoagulant of choice in the $\mathrm{PCl}$ setting (Tab. 1).

\section{Black clouds over bivalirudin according to the recent trials}

A recently published an open-label, single centre, randomized HEAT-PPCI (How Effective are Antithrombotic Therapies in Primary Percutaneous Coronary Intervention) trial comparing bivalirudin v. UFH alone in the STEMI setting unexpectedly revealed an excess of cardiac ischemic events (the primary efficacy outcome - a composite of all-cause mortality, cerebrovascular accident, re-MI, or unplanned target lesion revascularization: $8.7 \%$ v. 5.7\%; RR 1.52; 95\% Cl 1.09-2.13; $\mathrm{p}=0.01$ ) associated with bivalirudin therapy, which was predominantly driven by the significantly increased rate of $\mathrm{Ml}$ in the bivalirudin group $(2.7 \%$ v. $0.9 \%$; RR 3.01 ; 95\% Cl 1.36-6.66; $p=0.004)$, and no difference in major bleeding events between both study arms (type 3-5 bleedings according to the Bleeding Academic Research Consortium classification: $3.5 \%$ v. 3.1\%; RR 1.15; 95\% Cl 0.70-1.89; $p=0.59$ ) [26].

These data suggest that the inconsistency between the results of the HEAT-PPCI trial and the previously conducted studies may be driven by the concomitant administration of a glycoprotein Ilb/Illa inhibitor in heparin-treated patients. A recently published meta-analysis of 13 randomized studies including 24,605 patients showed that the incidence of 30-day all-cause death as well as 30-day MI did not differ significantly between the bivalirudin and UFH groups, independently of the concomitant use of a glycoprotein IIb/IIla inhibitor $[20,22,26-39]$. The rate of 30-day major bleeding events was significantly lower in bivalirudin-treated patients as compared with those receiving UFH with the routine use of a glycoprotein Ilb/llla inhibitor (odds ratio [OR] 0.52; 95\% $\mathrm{Cl} 0.45-0.60 ; \mathrm{p}<0.001$ ), but not if compared with the UFH plus provisional administration of a glycoprotein Ilb/llla inhibitor group (OR $0.66,95 \% \mathrm{Cl} 0.33-1.32 ; \mathrm{p}=0.24)$. The overall rate of 30-day definite stent thrombosis increased significantly with bivalirudin as compared with coadministration of UFH and a glycoprotein IIb/IIla inhibitor (OR 1.67; 95\% Cl $1.13-2.45 ; p=0.01)$. The prevalence of stent thrombosis was also numerically greater with bivalirudin as compared with heparin plus provisionally administered glycoprotein Ilb/llla inhibitor. However, the difference did not reach statistical significance (OR 2.08; 95\% Cl $0.35-12.32 ; p=0.42)$. Bivalirudin treatment was associated with a significant increase in the odds of acute stent thrombosis $(\leq 24 \mathrm{~h})$, but not of subacute stent thrombosis ( $>24 \mathrm{~h}-30$ days), when compared with heparin administration (acute stent thrombosis: OR 4.49; 95\% Cl 2.42-8.36; $p<0.001$; subacute stent thrombosis: OR 1.10; 95\% Cl 0.62-1.97; $p=0.74)$. The magnitude and direction of the estimates were consistent independently from the use of a glycoprotein llb/llla inhibitor in UFH-treated patients. The overall effect of the treatment, however, is reflected by the net adverse clinical events (NACE) rate, defined as a composite of ischemic events (death, MI, repeat revascularization, along with ST and stroke) and major bleeding. There were significantly fewer NACE with bivalirudin compared with UFH plus the routine use of a glycoprotein Ilb/Illa inhibitor (OR 0.77; 95\% Cl 0.65-0.91; $\mathrm{p}=0.002$ ). A numerical reduction in the odds of NACE in bivalirudin-treated patients was not-significant as compared with UFH without the routine use of a glycoprotein Ilb/lla inhibitor (OR 0.76; 95\% Cl 0.51-1.13; $p=0.18$ ) [39]. Another recent meta-analysis by Kianoush et al. including 41,243 patients from 25 randomized trials, demonstrated that the use of bivalirudin compared with active control was associated with an increased risk of definite stent thrombosis (RR 1.73; 95\% Cl 1.24-2.40; $\mathrm{p}<0.001$; number needed to harm [NNH] 182), similar risk of $\mathrm{MI}$ (RR 1.00; 95\% Cl 0.87-1.16; $\mathrm{p}=0.96$ ), decreased risk of major bleeding (RR $0.59 ; 95 \% \mathrm{Cl}$ $0.49-0.72 ; p<0.001$; number needed to treat [NNT] 79) and of cardiac death (RR $0.72 ; 95 \% \mathrm{Cl} 0.53-0.99$; $\mathrm{p}=0.05$ ), but no effect on all-cause mortality (RR 0.96 ; 95\% Cl 0.81-1.15; $p=0.69$ ) [40].

All available research evidence consistently shows that therapy with bivalirudin in ACS patients is associated with a significant reduction of major bleeding when compared with the regimen including UFH and 
Table 1. Recommendations of the European Society of Cardiology on the anticoagulation in patients undergoing PCI, with a particular emphasis on the use of bivalirudin

\begin{tabular}{llc}
\hline CAD & Recommendation & Class of \\
setting & & Level of \\
recommendation & evidence
\end{tabular}

2011 ESC Guidelines on NSTE-ACS [5]

NSTE-ACS Bivalirudin plus provisional GP Ilb/llla receptor inhibitors are recommended I B as an alternative to UFH plus GP Ilb/lla receptor inhibitors in patients with an intended urgent or early invasive strategy, particularly in patients with high risk of bleeding

2012 ESC Guidelines on STEMI [2]

STEMI Bivalirudin (with use of GP Ilb/llla blocker restricted to bailout) is recommended over UFH and a GP Ilb/llla blocker

Enoxaparin (with or without routine GP Ilb/lla blocker) may be preferred over unfractionated heparin

Unfractionated heparin with or without routine GP IIb/Illa blocker must be used in patients not receiving bivalirudin, or enoxaparin

Fondaparinux is not recommended for primary $\mathrm{PCl}$

idelines on myocardial revascularization [6]

2014 ESC Guidelines on myocard
SCAD UFH $70-100 \mathrm{U} / \mathrm{kg}$

Bivalirudin $(0.75 \mathrm{mg} / \mathrm{kg}$ bolus, followed by $1.75 \mathrm{mg} / \mathrm{kg} / \mathrm{h}$ for up to $4 \mathrm{~h}$ after the procedure) in case of heparin-induced thrombocytopenia

Bivalirudin $(0.75 \mathrm{mg} / \mathrm{kg}$ bolus, followed by $1.75 \mathrm{mg} / \mathrm{kg} / \mathrm{h}$ during the procedure) in patients at high bleeding risk

Enoxaparin i.v. $0.5 \mathrm{mg} / \mathrm{kg}$

STEMI The anticoagulation is selected according to both ischemic and bleeding risks, and according to the efficacy-safety profile of the chosen agent

Unfractionated heparin: 70-100 U/kg i.v. bolus when no GP Ilb/llla inhibitor is planned; $50-70 \mathrm{U} / \mathrm{kg}$ i.v. bolus with GP Ilb/llla inhibitor

Bivalirudin $0.75 \mathrm{mg} / \mathrm{kg}$ i.v. bolus, followed by i.v. infusion of $1.75 \mathrm{mg} / \mathrm{kg} / \mathrm{h}$ for up to $4 \mathrm{~h}$ after the procedure

Enoxaparin i.v. $0.5 \mathrm{mg} / \mathrm{kg}$ with or without GP Ilb/llla inhibitor

NSTE-ACS The anticoagulation is selected according to both ischemic and bleeding risks, and according to the efficacy-safety profile of the chosen agent

Bivalirudin $(0.75 \mathrm{mg} / \mathrm{kg}$ bolus, followed by $1.75 \mathrm{mg} / \mathrm{kg} / \mathrm{h}$ for up to $4 \mathrm{~h}$ after the procedure) is recommended as alternative to UFH plus GP Ilb/IIla receptor inhibitor during $\mathrm{PCl}$

$\mathrm{UFH}$ is recommended as anticoagulant for $\mathrm{PCl}$ if patients cannot receive bivalirudin

Enoxaparin should be considered as anticoagulant for $\mathrm{PCl}$ in patients pretreated with subcutaneous enoxaparin

\section{ESC Guidelines on NSTE-ACS [7]}

NSTE-ACS Bivalirudin $(0.75 \mathrm{mg} / \mathrm{kg}$ i.v. bolus, followed by $1.75 \mathrm{mg} / \mathrm{kg} / \mathrm{h}$ for up to $4 \mathrm{~h}$ after the procedure) is recommended as an alternative to UFH plus GP Ilb/llla inhibitors during PCl

NSTE-ACS UFH 70-100 IU/kg i.v. (50-70 IU/kg if concomitant with GPIlb/llla inhibitors) is recommended in patients undergoing $\mathrm{PCl}$ who did not receive any anticoagulant

NSTE-ACS Enoxaparin should be considered as an anticoagulant for $\mathrm{PCl}$ in patients pretreated with S.c. enoxaparin
A

Ila $\quad$ B

B

B

C

B

B

C

A

B

C

C

C

A

C

B

A

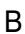

Ila

B

CAD - coronary artery disease; ECS - European Society of Cardiology; GP - glycoprotein; NSTE-ACS - non-ST-segment elevation acute coronary syndrome; $\mathrm{PCl}$ - percutaneous coronary intervention; SCAD — stable coronary artery disease; STEMI — ST-segment elevation myocardial infarction; UFH - unfractionated heparin 
a glycoprotein Ilb/Illa inhibitor. Bivalirudin also poses an increased risk of acute stent thrombosis when compared with heparin routinely or provisionally coadministered with a glycoprotein IIb/IIla inhibitor. These facts together with a short half-life of bivalirudin (around $25 \mathrm{~min}$ ) led to the formulation of the hypothesis that excessive rates of stent thrombosis and $\mathrm{Ml}$ observed in bivalirudin-treated patients may be related to the short duration of bivalirudin infusion and/or the timing and potency of the administered antiplatelet agents [41]. This hypothesis was initially supported by a study published by Cortese et al. [42]. The authors compared the effects of bivalirudin given as a bolus followed by 4-hour infusion v. bivalirudin given as a bolus followed by peri-PCI infusion v. a bolus of UFH on top of abciximab. The study population consisted of 264 STEMI patients undergoing primary $\mathrm{PCI}$ who were pretreated with aspirin and clopidogrel. The primary study end point, defined as $>70 \%$ ST-segment resolution within 90 minutes after $\mathrm{PCl}$, was achieved in $69.8 \%, 48.8 \%$, and $69.6 \%$ of patients, respectively ( $p=0.048$ for the comparison between the prolonged and standard bivalirudin infusion groups, $p=0.98$ for the comparison between the prolonged bivalirudin infusion and UFH plus abciximab groups). Major bleedings were not significantly different among the study arms. The encouraging results suggested that the strategy of prolonged bivalirudin infusion after primary $\mathrm{PCl}$, but not peri-PCl bivalirudin infusion, may be equivalent to the strategy with UFH plus abciximab in the STEMI setting [42].

However, this enthusiasm was tempered by the recently published findings of the MATRIX (Minimizing Adverse Haemorrhagic Events by TRansradial Access Site and Systemic Implementation of angioX) trial [43]. The investigators randomly assigned 7,213 ACS patients for whom $\mathrm{PCl}$ was anticipated to receive either bivalirudin or UFH. Patients in the bivalirudin group were subsequently randomly assigned to receive or not to receive a post- $\mathrm{PCI}$ bivalirudin infusion. Primary outcomes for the comparison between bivalirudin and heparin were the occurrence of major adverse cardiovascular events (a composite of death, myocardial infarction, or stroke) and net adverse clinical events (a composite of major bleeding or a major adverse cardiovascular event). Clinical follow-up was performed at 30 days. The primary outcome for the comparison of a post- $\mathrm{PCl}$ bivalirudin infusion with no post-PCl infusion was a composite of urgent target-vessel revascularization, definite stent thrombosis, or net adverse clinical events. Bivalirudin failed to reduce the rates of both major adverse cardiovascular events (10.3\% v. 10.9\%; RR 0.94; 95\% Cl 0.81-1.09; $\mathrm{p}=0.44)$ and net adverse clinical events $(11.2 \%$ v. $12.4 \%$; RR $0.89 ; 95 \% \mathrm{Cl} 0.78-1.03 ; \mathrm{p}=0.12$ ) as compared with UFH. Moreover, post-PCI bivalirudin infusion, as compared with no infusion, did not significantly decrease the rate of urgent target-vessel revascularization, definite stent thrombosis, or net adverse clinical events (11.0\% v. $11.9 \%$; RR $0.91 ; 95 \%$ Cl $0.74-1.11 ; p=0.34)$. In this study, there was no significant difference in the rate of definite or probable stent thrombosis between the groups (1.3\% v. $1.0 \%$; RR 1.28; 95\% Cl 0.82-2.00; $p=0.27$ ), although the rate of definite stent thrombosis was higher in the bivalirudin group (1.0\% v. 0.6\%; RR $1.71 ; 95 \% \mathrm{Cl}$ $1.00-2.93 ; p=0.048)$. Contrary to the expectations, post- $\mathrm{PCl}$ infusion of bivalirudin, as compared with no post-PCl infusion, did not lower the rate of definite stent thrombosis (1.3\% v. $0.7 \%$; RR $1.78 ; 95 \% \mathrm{Cl}$ $0.90-3.53 ; p=0.09$ ) [43]. Consistently with some of the previous reports $[22,25]$, the MATRIX investigators found a lower rate of major bleeding $(1.7 \%$ v. $2.3 \%$; RR $0.71 ; 95 \% \mathrm{Cl} 0.51-0.99 ; \mathrm{p}=0.04)$ and lower all-cause mortality (1.4\% v. 2.5\%; RR 0.55; 95\% Cl 0.39-0.78; $\mathrm{p}<0.001$ ) in bivalirudin v. UFH-treated patients [43]. Interestingly, the authors raised the issue of the differences in definitions of individual elements of composite outcomes in other studies which might have influenced the interpretation of their results. However, the definition of re-MI used in the MATRIX study was in agreement with the third universal definition of myocardial infarction.

In general, the results of the recently published randomized studies are much less favorable for bivalirudin than the initial ones (Tab. 2) [20-45]. This fact is reflected in the latest guidelines of the European Society of Cardiology where the role of bivalirudin in patients undergoing $\mathrm{PCl}$ was considerably downgraded (Tab. 1). The discrepancy in the trial results may be multicausal. First of all, some of the landmark studies (e.g. the HORIZONS-AMI trial) were suboptimally designed, favoring bivalirudin. The bleeding benefit identified in the older studies seems to be caused rather by a higher bleeding incidence in the comparator arm due to the disproportional use of a glycoprotein IIb/IIla inhibitor with heparin than beneficial properties of bivalirudin. Additionally, recent changes in interventional practice, such as increasing use of radial access, lower doses of UFH, decreased use of glycoprotein IIb/IIla inhibitors and administration of more effective platelet $\mathrm{P} 2 \mathrm{Y} 12$ receptor inhibitors, are suggested to diminish the benefits of bivalirudin v. UFH therapy. Although bivalirudin is currently reimbursed in the majority of European countries, including Poland, pharmacoeconomic considerations clearly favor UFH or enoxaparin over bivalirudin in the $\mathrm{PCl}$ setting. 


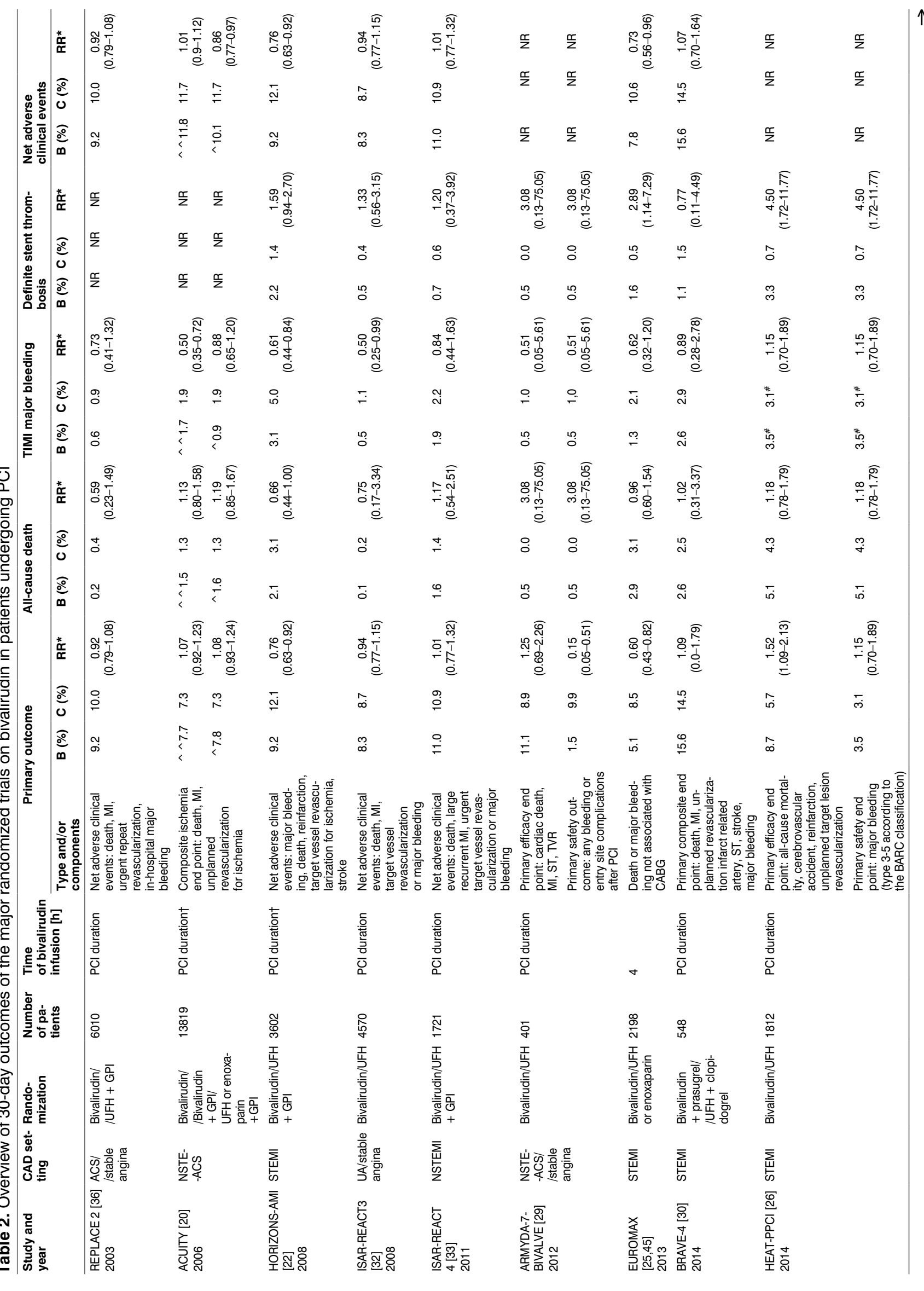




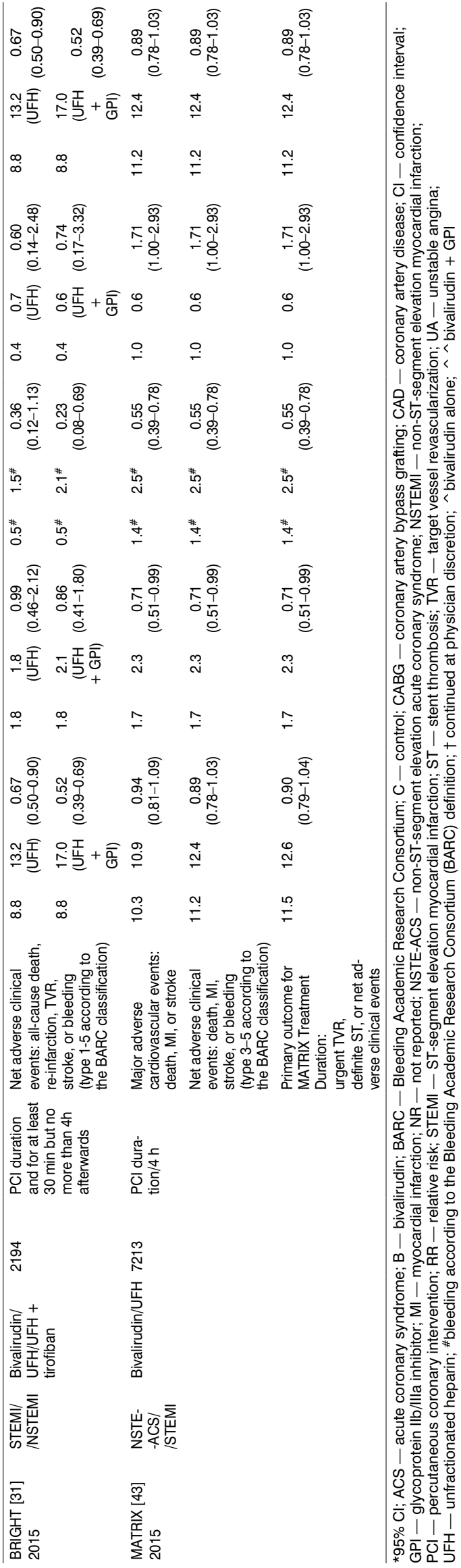

\section{Conclusions}

In our opinion, the research evidence and pharmacoeconomic considerations presented above strongly support the use of bivalirudin in $\mathrm{PCl}$ patients at high risk of bleeding complications, while in other situations old and inexpensive UFH or enoxaparin remain the first line antithrombotic drugs.

\section{Conflict of interest}

Prof. Grzegorz Grześk received honoraria for the lectures from The Medicines Company, the manufacturer of bivalirudin. All other authors have reported that they have no relevant competing interests to disclose.

\section{References}

1. Cardiovascular diseases (Updated January 2015). Website of the World Health Organization. http://www.who.int/mediacentre/factsheets/fs317/en/ (Accessed 03.09.2015).

2. Steg PG, James SK, Atar D et al. ESC Guidelines for the management of acute myocardial infarction in patients presenting with ST-segment elevation. Eur Heart J 2012; 33: 2569-2619.

3. Gurbel PA, Navarese EP, Tantry US. What is the best anticoagulant therapy during primary percutaneous coronary intervention for acute myocardial infarction? Pol Arch Med Wewn 2015; 125: 461-470.

4. $\mathrm{Xu} Y$, Wu W, Wang $L$ et al. Differential profiles of thrombin inhibitors (heparin, hirudin, bivalirudin, and dabigatran) in the thrombin generation assay and thromboelastography in vitro. Blood Coagul Fibrinolysis 2013; 24: 332-338.

5. Hamm CW, Bassand JP, Agewall S et al. ESC Guidelines for the management of acute coronary syndromes in patients presenting without persistent ST-segment elevation. Eur Heart J 2011; 32, 2999-3054.

6. Windecker S, Kolh P Alfonso F et al. 2014 ESC/EACTS Guidelines on myocardial revascularization: The Task Force on Myocardial Revascularization of the European Society of Cardiology (ESC) and the European Association for Cardio-Thoracic Surgery (EACTS) Developed with the special contribution of the European Association of Percutaneous Cardiovascular Interventions (EAPCI). Eur Heart J 2014; 35: 2541-2619

7. Roffi M, Patrono C, Collet JP et al. 2015 ESC Guidelines for the management of acute coronary syndromes in patients presenting without persistent ST-segment elevation. Eur Heart J 2015. doi:10.1093/eurheartj/ehv320 [Epub ahead of print].

8. Navarese EP, De Luca G, Castriota F et al. Low-molecular-weight heparins vs. unfractionated heparin in the setting of percutaneous coronary intervention for ST-elevation myocardial infarction: a meta-analysis. J Thromb Haemost 2011; 9: 1902-1915.

9. Koziński M, Grześk G, Kubica J. Optimal antiplatelet and antithrombotic therapy in patients with ST elevation myocardial infarction. Kardiol Pol 2012; 70: 206-212.

10. Moher D, Liberati A, Tetzlaff $\mathrm{J}$ et al. Preferred reporting items for systematic reviews and meta-analyses: the PRISMA statement. Ann Intern Med 2009; 151: 264-269.

11. Huntington JA, Baglin TP. Targeting thrombin — rational drug design from natural mechanisms. Trends Pharmacol Sci 2003; 24: 589-595.

12. Bates SM, Weitz JI. The mechanism of action of thrombin inhibitors. J Invasive Cardiol 2000; 12 (suppl. F): 27F-32F.

13. Hirsh J, Warkentin TE, Shaughnessy SG et al. Heparin and low-molecular-weight heparin: mechanisms of action, pharmacokinetics, dosing, monitoring, efficacy, and safety. Chest 2001; 119 : 64S-94S

14. Butenas S, Orfeo T, Brummel-Ziedins KE, Mann KG. Influence of bivalirudin on tissue factor-triggered coagulation. Blood Coagul Fibrinolysis 2007: 18: 407-414

15. Tanaka KA, Szlam F, Sun HY, Taketomi T, Levy JH. Thrombin generation assay and viscoelastic coagulation monitors demonstrate differences in the mode of thrombin inhibition between unfractionated heparin and bivalirudin. Anesth Analg 2007; 105: 933-939. 
16. Anand SX, Kim MC, Kamran M et al. Comparison of platelet function and morphology in patients undergoing percutaneous coronary intervention receiving bivalirudin versus unfractionated heparin versus clopidogrel pretreatment and bivalirudin. Am J Cardiol 2007 100: 417-424.

17. Busch G, Steppich B, Sibbing D et al. Bivalirudin reduces platelet and monocyte activation after elective percutaneous coronary intervention. Thromb Haemost 2009; 101: 340-344.

18. Eslam RB, Reiter N, Kaider A, Lang IM, Panzer S. High-shear- and thrombin-inducible platelet adhesion and aggregation in patients undergoing percutaneous coronary intervention. Effects of unfractionated heparin versus bivalirudin. Thromb Haemost 2011; 105: 496-500.

19. Pepke W, Eisenreich $A$, Jaster $M$ et al. Bivalirudin inhibits periprocedura platelet function and tissue factor expression of human smooth muscle cells. Cardiovasc Ther 2013; 31: 115-123.

20. Stone GW, McLaurin BT, Cox DA et al. Bivalirudin for patients with acute coronary syndromes. N Engl J Med 2006; 355: 2203-2216.

21. Stone GW, Ware $\mathrm{JH}$, Bertrand $\mathrm{ME}$ et al. Antithrombotic strategies in patients with acute coronary syndromes undergoing early invasive management: one-year results from the ACUITY trial. JAMA 2007; 298: 2497-2506.

22. Stone GW, Witzenbichler B, Guagliumi $G$ et al. Bivalirudin during primary PCl in acute myocardial infarction. N Engl J Med 2008; 358: 2218-2230.

23. Stone GW, Witzenbichler B, Guagliumi G et al. Heparin plus a glycoprotein Ilb/Illa inhibitor versus bivalirudin monotherapy and paclitaxel-eluting stents versus bare-metal stents in acute myocardial infarction (HORIZONS-AMI): final 3-year results from a multicentre, randomised controlled trial. Lancet 2011; 377: 2193-2204.

24. Steg PG, van 't Hof A, Clemmensen $P$ et al. Design and methods of European Ambulance Acute Coronary Syndrome Angiography Trial (EUROMAX): an international randomized open-label ambulance trial of bivalirudin versus standard-of-care anticoagulation in patients with acute ST-segment-elevation myocardial infarction transferred for primary percutaneous coronary intervention. Am Heart J 2013; 166: 960-967.

25. Steg PG, van 't Hof A, Hamm CW et al. Bivalirudin started during emergency transport for primary PCI. N Engl J Med 2013; 369: 2207-2217.

26. Shahzad A Kemp I, Mars C et al. Unfractionated heparin versus bivalirudin in primary percutaneous coronary intervention (HEAT-PPCI) an open-label, single centre, randomised controlled trial. Lancet 2014 384: 1849-1858.

27. Aoki J, Lansky AJ, Mehran R et al. Early stent thrombosis in patients with acute coronary syndromes treated with drug-eluting and bare metal stents: the Acute Catheterization and Urgent Intervention Triage Strategy trial. Circulation 2009; 119: 687-698.

28. Aoki J, Stone GW, Mehran R, et al. Subacute Stent Thrombosis in Patients with Acute Coronary Syndromes Treated with Bare Metal and Drug-Eluting Stents: The ACUITY Trial. Website: Clinical Trial Results. www.clinicaltrialresults.org/Slides/aha\%202007\%20acuity\%20 sat.ppt (Accessed 03.09.2015).

29. Patti G Pasceri V. D'Antonio L et al. Comparison of safety and efficacy of bivalirudin versus unfractionated heparin in high-risk patients undergoing percutaneous coronary intervention (from the Anti-Thrombotic Strategy for Reduction of Myocardial Damage During Angioplasty-Bivalirudin vs Heparin study). Am J Cardiol 2012; 110: 478-484.

30. Schulz S, Richardt G, Laugwitz KL et al. Prasugrel plus bivalirudin vs. clopidogrel plus heparin in patients with ST-segment elevation myocardial infarction. Eur Heart J 2014; 35: 2285-2294.

31. Han Y, Guo J, Zheng $Y$ et al. Bivalirudin vs heparin with or without tirofiban during primary percutaneous coronary intervention in acute myocardial infarction: the BRIGHT randomized clinical trial. JAMA 2015; 313: 1336-1346.

32. Kastrati A, Neumann FJ, Mehilli J et al. Bivalirudin versus unfractionated heparin during percutaneous coronary intervention. N Engl J Med 2008: 359: 688-696.

33. Kastrati A, Neumann FJ, Schulz S et al. Abciximab and heparin versus bivalirudin for non-ST-elevation myocardial infarction. N Engl J Med 2011: 365: 1980-1989.

34. Gibson CM, Morrow DA, Murphy SA et al. A randomized trial to evaluate the relative protection against post-percutaneous coronary intervention microvascular dysfunction, ischemia, and inflammation among antiplatelet and antithrombotic agents: the PROTECT-TIMI-30 trial. J Am Coll Cardiol 2006; 47: 2364-2373.

35. Ray MJ, Juneja M, Bett N, Walters DL. A comparison of anticoagulation with bivalirudin and provisional GPIlb/Illa inhibition with unfractionated heparin and mandatory GPIIb/IIla inhibition during percutaneous coronary intervention in relation to platelet activation and the inhibition of coagulation. Eurolntervention 2009; 5: 330-335.

36. Lincoff AM, Bittl JA, Harrington RA et al. Bivalirudin and provisional glycoprotein Ilb/llla blockade compared with heparin and planned glycoprotein Ilb/llla blockade during percutaneous coronary intervention: REPLACE-2 randomized trial. JAMA 2003; 289: 853-863.

37. Rajagopal V, Lincoff AM, Cohen DJ et al. Outcomes of patients with acute coronary syndromes who are treated with bivalirudin during percutaneous coronary intervention: an analysis from the Randomized Evaluation in PCI Linking Angiomax to Reduced Clinical Events (REPLACE-2) trial. Am Heart J 2006; 152: 149-154.

38. Antman EM, McCabe $\mathrm{CH}$, Braunwald E. Bivalirudin as a replacement for unfractionated heparin in unstable angina/non-ST-elevation myocardial infarction: Observations from the TIMI 8 trial. Am Heart J 2002: 143: 229-234

39. Navarese EP, Schulze V, Andreotti F et al. Comprehensive meta-analysis of safety and efficacy of bivalirudin versus heparin with or without routine glycoprotein Ilb/llla inhibitors in patients with acute coronary syndrome. JACC Cardiovasc Interv 2015; 8: 201-213.

40. Kianoush S, Bikdeli B, Desai MM, Eikelboom JW. Risk of Stent Thrombosis and Major Bleeding with Bivalirudin Compared with Active Control: A Systematic Review and Meta-analysis of Randomized Trials. Thromb Res 2015. doi: 10.1016/j.thromres.2015.06.001 [Epub ahead of print].

41. Moser LR, Nemerovski CW, Good KL. Use of prolonged bivalirudin infusions following percutaneous coronary intervention. Cardiovasc Drugs Ther 2011; 25: 267-276.

42. Cortese B, Limbruno U, Severi S et al. Effect of prolonged Bivalirudin infusion on ST-segment resolution following primary percutaneous coronary intervention (from the PROBI VIRI 2 study). Am J Cardiol 2011; 108: 1220-1224.

43. Valgimigli M, Frigoli E, Leonardi S et al. Bivalirudin or Unfractionated Heparin in Acute Coronary Syndromes. N Engl J Med 2015; 373: 997-1009.

44. Waksman R1, Bertrand $\mathrm{O}$, Driesman $\mathrm{M}$ et al. Bivalirudin versus unfractionated heparin during percutaneous coronary intervention in patients with non-ST-segment elevation acute coronary syndrome initially treated with fondaparinux: results from an international, multicenter, randomized pilot study (SWITCH III). J Interv Cardiol 2013; 26: $107-113$.

45. Zeymer $\mathrm{U}$, van 't Hof $\mathrm{A}$, Adgey $\mathrm{J}$ et al. Bivalirudin is superior to heparins alone with bailout GP $\mathrm{lb} / \mathrm{llla}$ inhibitors in patients with ST-segment elevation myocardial infarction transported emergently for primary percutaneous coronary intervention: a pre-specified analysis from the EUROMAX trial. Eur Heart J 2014; 35: 2460-2467. 